\title{
Илаева 3.М.
}

\section{Теоретические основания исследования мотивации предпринимательства}

ФГБОУ ВО «Чеченский государственный университет имени А.А.Кадырова»

(Россия, Грозный)

doi: 10.18411/trnio-12-2021-23

\section{Аннотация}

Анализ теоретических подходов к исследованию предпринимательства является актуальным в настоящее время, так как на основе выявленных его качественных характеристиках можно разработать новые направления развития предпринимательства. К исследованию феномена предпринимательства обращались зарубежные и российские социологи и экономисты.

Таким образом, в статье сделан вывод, что постепенное изучение предпринимателя с точки зрения экономического и социологического подходов расширяется до рассмотрения бизнесмена как части социально-экономической структуры общества, до детального рассмотрения широкого спектра его функций в социуме.

Ключевые слова: предпринимательство, теории, исследования, экономический подход, социологический подход.

\section{Abstract}

The analysis of theoretical approaches to the study of entrepreneurship is relevant at the present time, since on the basis of its identified qualitative characteristics, it is possible to develop new directions for the development of youth entrepreneurship. Foreign and Russian sociologists and economists turned to the study of the phenomenon of entrepreneurship.

Thus, the article concludes that the gradual study of the entrepreneur from the point of view of economic and sociological approaches extends to considering the businessman as part of the socio-economic structure of society, to a detailed examination of a wide range of his functions in society.

Keywords: entrepreneurship, theory, research, economic approach, sociological approach.

Истоки научного рассмотрения предпринимательства берут начало в 18 в.: изначально преобладающим являлся экономический подход к анализу данной сферы деятельности, а предпринимательство рассматривалось, в первую очередь, как экономическая функция, выполнение которой сопровождалось для человека несением бремени риска и неопределённости.

Так, впервые термин «предпринимательство» использует экономист и банкир

Ричард Кантильон в книге «Очерк о природе торговли», которая была издана

в Лондоне 1755 г. [1] Кантильон рассматривал проблему природы прибыли и находился в поиске причин экономического роста. Под предпринимателем он понимал лицо, которое по известной цене приобретает товар, но продаёт его по заранее не зафиксированной стоимости, то есть рискует, чтобы обрести прибыль, которая также является непредсказуемой. Эта ориентация на получение максимальной прибыли приводит к тому, что риск и готовность к потерям являются определяющими чертами предпринимателя. Также, по Кантильону, предприниматель - это индивид, который устремлён в будущее, открыт к инновационной деятельности и обладает предрасположенностью к прогнозированию ситуации на рынке. Последователями данной теории стали представители немецкой классической школы 19 в. И. Тюнен и Г.Мангольдт, а американский экономист Ф. Найт, продолжая эту мысль, определял предпринимателя как «берущего на себя бремя подлинной неопределённости и избавляющий от неё своих поставщиков» [2] . 
Движение экономической мысли развивается во многом параллельно с изменением реальной роли предпринимателя. Всё чаще бизнесмена определяют как организатора производства, а вопрос о том, есть ли у него при этом права собственности, становится второстепенным. Подобного взгляда придерживаются, например, Ж.Б. Сэй и Дж.С. Милль [3]. В 19 в. Карл Маркс чётко проводит функциональное разграничение между собственником и предпринимателем. Так, вне процесса производства теперь стоит собственник, то есть капиталист-собственность, а активное участие в производстве принимает капиталист-функция. Переосмысляя роль предпринимателя с точки зрения коммунистических идеалов, Маркс считал деятельность бизнесмена губительной для народных масс: она приводит к обеднению населения, потому как предприниматель, извлекая из производства прибыль, экономит на заработной плате для рабочей силы.

Предпринимателя как менеджера рассматривают в своих трудах неоклассики экономической мысли А. Маршалл, Л. Вальрас, К. Менгер, Ф. Визер. Содержание предпринимательской функции неоклассики видят в приспособлении производства к изменяющимся условиям рынка. Также суть деятельности бизнесмена представители экономического подхода видят в удовлетворении возникающего спроса, максимально эффективном использовании ресурсов, восстановлении нарушенного баланса в экономике, регуляции цен. То есть с точки зрения экономической теории предприниматель становится не только регулятором рынка, но и его созидателем и преобразователем [4] .

Подробно на новаторской составляющей деятельности предпринимателя остановился австро-американский исследователь Йозеф Шумпетер. В труде «Теория экономического развития» он описал генезис предпринимательской деятельности с точки зрения не только экономических функций, но и оценив социальную роль предпринимателя в обществе.

Ученый считал, что «предприниматель - это хозяйственный субъект, главной задачей которого является реализация новых комбинаций, выступающих как активный элемент» [5].

Идеи Шумпетера нашли отклик и в российской социологии: активным продолжателем его концепции предпринимательской деятельности можно считать В.В. Радаева. Он помимо определения предпринимательства как осуществления организационной инновации с целью извлечения прибыли или иного дополнительного дохода перечисляет три составляющих предпринимательства. Это - организационное действие, инициирование изменений и денежный доход как цель и критерий успешности.

Рассмотрев основных представителей экономического подхода, можно дать объединённую характеристику предпринимательства: это разновидность хозяйственной деятельности, целью которой является получение максимальной прибыли; при этом данная деятельность носит инновационный характер, осуществляется в слабопредсказуемых условиях и отличается рискованностью.

Социологический подход в изучении предпринимательства предопределил Й. Шумпетер, который в «Теории экономического развития» подчёркивает, что бизнесмены образуют не отдельный класс, а выполняют в том числе важную социальную функцию, которую время от времени осуществляют разные люди. Исследователямипервопроходцами, которые рассмотрели предпринимательство с точки зрения исторических и религиозных предпосылок капитализма, стали немецкие учёные М. Вебер и В. Зомбарт.

Зомбарт при исследовании феномена предпринимательства выступает продолжателем социологического подхода, однако, признавая исторические предпосылки капиталистического духа, он сосредоточился на многообразии черт капиталиста. Если у М.Вебера основными факторами развития предпринимательства является усложнение структуры предприятия, бюрократизация общества, то Зомбарт связывает развитие ового капиталистического духа несколько с другими изменениями. Он подчёркивает, что человек-капиталист, объединяя в себе и предпринимательский, и мещанский дух, является 
двойственной натурой. То есть предпринимательский дух существовал и прежде, и отличается он, например, изобретательностью, жаждой наживы, любовью к приключениям.

$\begin{array}{llcccc}\text { Однако в предпринимателе он объединился с духом мещанским, а это - } \\ \text { стремление } & \text { к } & \text { благополучному } & \text { стабильному хозяйству, осмотрительность, }\end{array}$ нерасточительность. В результате капиталист одновременно обладает несколькими взаимодополняющими свойствами. От предпринимательского духа капиталист перенял триединство, то есть получил свойства.

1. Завоевателя. Ему свойственны упорство, духовная свобода, воля, энергия.

2. Организатора. Хорошо координирует действия людей, которые работают на его предприятии, умеет дать им верную характеристику.

3. Торговца. Внушает доверие, побуждает интерес к товару, обладает даром убеждения.

Таким образом, основные представители социологического подхода при исследовании предпринимательства проанализировали исторические, религиозные предпосылки формирования данной деятельности. В отличие от экономического подхода, который предпринимательство рассматривал преимущественно как экономическую функцию, а предпринимателя как человека, главная цель которого увеличение капитала в условиях неопределённости и риска, социологический подход представил более целостный, закономерно сформированный образ предпринимателя, объяснив часть его профессиональных черт влиянием предшествующих исторических периодов.

$$
* * *
$$

1. Блауг М. Очерк Кантильона М., 1994.

2. Найт Ф.Х. Риск, неопределенность и прибыль. М., 2003

3. Сэй Ж.Б. Трактат политической экономии. М., 1896.

4. Радаев В.В. Экономическая социология. Изд. дом ГУ-ВШЭ, 2005.

5. Шумпетер Й. А. Теория экономического развития. М., 1982.

\section{Илаева 3.М.}

Экологические аспекты реновации объектов индустриального наследия

ФГБОУ ВО «Чеченский государственный университет имени А.А.Кадырова»

(Россия, Грозный)

doi: 10.18411/trnio-12-2021-24

\section{Аннотация}

Актуальность исследования обусловлена тем, что на сегодняшний день процесс переосмысления промышленных зон в городах России имеет преимущественно подтекст экономической выгоды, тогда как экологическая сторона вопроса уходит на фоновый план или не затрагивается вовсе. Реализующиеся проекты реновации хоть и улучшают экологическое состояние территорий бывшего индустриального пользования, но совершенно не приближают городскую среду к «единению» с природой.

В статье рассматриваются экологические аспекты реновации индустриальных объектов, а также сделан вывод, что решения экологической проблемы требуется привлечение узкоспециализированных специалистов.

Ключевые слова: экология, реновация, город, экономика, индустриальные объекты, экономической выгода.

\section{Abstract}

The relevance of the study is due to the fact that today the process of rethinking industrial zones in Russian cities has mainly the subtext of economic benefits, while the environmental side of the issue goes into the background or is not touched upon at all. The ongoing renovation projects, 